\title{
Hematological and serum biochemical alterations in White Fulani cattle with tuberculous lesions
}

\author{
John I. Ihedioha ${ }^{1 *}$ Ikechukwu J. Udeani ${ }^{1}$ \\ Chukwunonso K. Ezeasor ${ }^{1}$
}

\section{Keywords}

Bos indicus, White Fulani cattle, tuberculosis, hematology, biochemistry, Nigeria

Submitted: 10 January 2017 Accepted: 5 February 2018 Published: 23 April 2018 DOI : $10.19182 /$ remvt.31531

\begin{abstract}
Summary
This study assessed hematological and serum biochemical alterations associated with the occurrence of tuberculous lesions in slaughtered White Fulani cattle at Nsukka abattoir, Enugu State, Nigeria. Diagnosis was confirmed by the immunochromatographic technique and histopathology. Out of 567 cattle examined, ten $(1.76 \%)$ had tuberculous lesions. The tuberculous cattle had normocytic normochromic anemia, leukocytosis, lymphocytosis, eosinophilia and an increased erythrocyte sedimentation rate. They also had significantly lower $(p<0.05)$ serum alanine aminotransferase, albumin and urea, and significantly higher $(p$ $<0.05)$ serum globulin than the apparently healthy control animals. We concluded that the occurrence of tubercles in cattle was associated with alterations in hematological and serum biochemical parameters, which may be relevant to the establishment of an antemortem diagnosis of tuberculosis.
\end{abstract}

- How to quote this article: Ihedioha J.I., Udeani I.J., Ezeasor C.K., 2017. Hematological and serum biochemical alterations in White Fulani cattle with tuberculous lesions. Rev. Elev. Med. Vet. Pays Trop., 70 (4): 127-130, doi: 10.19182/remvt.31531

\section{INTRODUCTION}

Bovine tuberculosis (TB) is a chronic infectious disease of animals and humans, caused by Mycobacterium bovis (Ayele et al., 2004). The disease in cattle occurs worldwide. It is associated with severe economic losses caused by the depreciation in cattle production, cattle mortality and condemnation of carcasses at slaughter (Abubakar

1. Department of Veterinary Pathology and Microbiology, Faculty of Veterinary Medicine, University of Nigeria, Nsukka, Enugu State, Nigeria.

* Corresponding author

Tel.: +234 80353871 56; Email: john.ihedioha@unn.edu.ng et al., 2011). Although clinical signs of the disease may not be obvious and specific in affected cattle, the development of tubercles in organs such as the lymph nodes, lungs, intestines, liver, spleen, pleura and peritoneum of affected cattle is characteristic (Corner, 1994; Varello et al., 2008).

Hematological and serum biochemical evaluations are important in the diagnosis of diseases because of their predictive value of pathological changes in vital internal organs and deviation from normal caused by invasion of the body by pathogens (Stockham and Scott, 2008). There have been many reports on hematological and serum biochemical changes associated with TB in cattle (Amin et al., 1990; Rao et al., 1992; Kumar et al., 1994; Javed et al., 2006; Olivia et al., 2008), but the present study assessed hematological and serum biochemical alterations in slaughtered cattle with gross tuberculous lesions at Nsukka abattoir. 


\section{MATERIALS AND METHODS}

We carried out a postmortem TB survey on trade cattle, consisting mostly (93\%) of White Fulani Zebu, slaughtered between March 2012 and March 2013 at Nsukka abattoir, Enugu State, Southeastern Nigeria, located within the derived savanna belt, at $6^{\circ} 51^{\prime} 24^{\prime \prime} \mathrm{N}$ and $7^{\circ} 23^{\prime} 45^{\prime \prime} \mathrm{E}$, with an average elevation of approximately 550 meters (1810 feet). The sample population comprised 567 cattle, slaughtered during the 27 abattoir visits (once every two weeks) during the 13-month study period. Cattle scheduled for slaughter were physically examined at the lairage and marked.

Blood samples were collected from the jugular vein. They were anticoagulated with sodium ethylene diamine tetra-acetic acid (EDTA) for hematology, whereas those for serum biochemistry were collected in plain glass test tubes and allowed to clot. A postmortem examination was performed on the carcasses for presence of tubercles (Corner, 1994), and blood samples from cattle with tubercles (positive cases) were retained. For each positive case, blood samples from four apparently healthy (non-tuberculous) cattle were also collected as control. The diagnosis of bovine TB was further confirmed by the histopathological evaluation of organs with tubercles (Varello et al., 2008) and the immunochromatographic technique using Anigen Rapid Bovine TB Antibody Test Kit (Bionote, South Korea), as its sensitivity and specificity are very high (Okoro et al., 2014).

The packed cell volume (PCV) was determined by the microhematocrit method (Thrall and Weiser, 2002). Hemoglobin (Hb) concentration was measured by the cyanmethemoglobin method (Burtis et al., 2008). Red blood cell (RBC) and total leukocyte counts were conducted with the hemocytometer method. Differential leukocyte counts were performed on air-dried thin blood smears stained by the Leishman technique and enumerated with the battlement method (Thrall and Weiser, 2002). The mean corpuscular volume (MCV), mean corpuscular hemoglobin $(\mathrm{MCH})$ and mean corpuscular hemoglobin concentration (MCHC) of the erythrocytes were calculated with the standard formula (Thrall and Weiser, 2002). The erythrocyte sedimentation rate (ESR) was determined with the modified Wintrobe method (Thrall and Weiser, 2002). All serum biochemical determinations were carried out with the standard colorimetric method using commercial test kits (Quimica Clinica Applicada, Spain). Serum aspartate aminotransferase (AST) and alanine aminotransferase (ALT) activities were determined by the Reitman-Frankel colorimetric method, and the alkaline phosphatase (ALP) activity by the phenolphthalein monophosphate method (Burtis et al., 2008). Serum total bilirubin was determined by the modified Jendrassik-Grof method, and total protein by the direct Biuret method (Burtis et al., 2008). Serum albumin was determined by the bromocresol green method, and globulin was calculated by subtraction of the value of albumin from that of total serum protein (Burtis et al., 2008). Serum total cholesterol was determined by the enzymatic colorimetric method, serum urea by the modified Berthelot-Searcy method, and creatinine by the modified Jaffe method (Burtis et al., 2008).

Data analysis was performed with the statistical Software Package for Social Sciences (SPSS) version 16. The hematological and serum biochemical parameters of control and tuberculous cattle were compared with Student's t-test (significance level of $\mathrm{p}<0.05$ ).

\section{- RESULTS AND DISCUSSION}

Out of the 567 cattle, ten (1.76\%) had tubercles on the lungs, liver, spleen, gall bladder and/or lymph nodes which were confirmed by the histopathology and immunochromatographic technique. The positive cases were six male and four female adult White Fulani cattle. The $1.76 \%$ prevalence of tuberculosis in the present study was comparable to the reported prevalences of $1.1 \%$ in Maiduguri (Raufu and Ameh,
2010) and 1.9\% in Makurdi (Ejeh et al., 2014a), in Nigeria. It was, however, relatively lower than those of 2.8\% (Igbokwe et al., 2001), 4.05\% (Aliyu et al., 2009) and 2.9-6.5\% (Ejeh et al., 2014b) reported in areas of Northern Nigeria. These differences may be associated, on one hand, with climatic conditions that facilitate bovine tuberculosis persistence and transmission, as they vary from north to south of Nigeria depending on the geographical location, and, on the other hand, with the methods of diagnosis of positive cases.

The hematological parameters are summarized in Table I. Mean PCV, $\mathrm{RBC}$ count and $\mathrm{Hb}$ concentration were significantly lower $(\mathrm{p}<0.05)$ in tuberculous cattle than in apparently healthy control animals, whereas mean ESR was significantly higher $(\mathrm{p}<0.05)$ in tuberculous cattle than in control animals. Mean total leukocyte, lymphocyte and eosinophil counts were significantly higher $(\mathrm{p}<0.05)$ in tuberculous cattle than in control, but the basophil count of tuberculous cattle was significantly lower $(\mathrm{p}<0.05)$ than that of control. There were no significant $(\mathrm{p}>$ 0.05 ) differences between means of $\mathrm{MCV}, \mathrm{MCH}, \mathrm{MCHC}$, neutrophil and monocyte counts in tuberculous cattle and in control cattle.

Erythrocytic alterations in tuberculous cattle showed normocytic normochromic anemia, indicated by significantly lower means of PCV, $\mathrm{RBC}$ count, and $\mathrm{Hb}$ concentration without any significant changes in their MCV, MCH and MCHC (Stockham and Scott, 2008). The anemia could have been caused by the chronic disease condition and the suppression of erythropoiesis by inflammatory mediators (Weiss, 2002; Lee et al., 2006). The finding of normocytic normochromic anemia is in agreement with other reports in cattle (Rao et al., 1992; Kumar et al., 1994) and humans with tuberculosis (Lee et al., 2006). The higher ESR could have been caused by tissue destruction associated with the formation of granulomas in the parenchyma of the lungs, liver, spleen and lymph nodes (Stockham and Scott, 2008). It agreed with reports on buffaloes (Amin et al., 1990) and humans (Olaniyi and Aken'ova, 2003; Olivia et al., 2008), but disagreed with another report on buffaloes (Javed et al., 2006). Leukocytosis associated with lymphocytosis and eosinophilia in the present study could have been due to an antigenic

\section{Table I}

Hematological values (mean \pm standard error) of apparently healthy and tuberculous slaughtered cattle at Nsukka abattoir, Nigeria

\begin{tabular}{lcc} 
Hematology & $\begin{array}{c}\text { Tuberculous } \\
\text { cattle } \\
(\mathbf{n}=\mathbf{1 0})\end{array}$ & $\begin{array}{c}\text { Apparently } \\
\text { healthy cattle } \\
(\mathbf{n}=\mathbf{4 0})\end{array}$ \\
\hline Packed cell volume $(\%)$ & $24.95 \pm 1.06^{\mathrm{a}}$ & $34.75 \pm 0.52^{\mathrm{b}}$ \\
Red blood cell count $\left(10^{6} / \mu \mathrm{l}\right)$ & $6.00 \pm 0.51^{\mathrm{a}}$ & $7.90 \pm 0.30^{\mathrm{b}}$ \\
Hemoglobin concentration $(\mathrm{g} / \mathrm{dl})$ & $9.56 \pm 0.48^{\mathrm{a}}$ & $13.15 \pm 0.28^{\mathrm{b}}$ \\
Mean corpuscular volume $(\mathrm{fl})$ & $44.08 \pm 3.25$ & $45.19 \pm 1.46$ \\
Mean corpuscular hemoglobin & $17.00 \pm 1.51$ & $17.74 \pm 0.75$ \\
concentration $(\mathrm{pg})$ & & \\
Mean corpuscular hemoglobin & $38.57 \pm 2.28$ & $37.96 \pm 0.82$ \\
concentration $(\mathrm{g} / \mathrm{dl})$ & $29.96 \pm 5.26^{\mathrm{a}}$ & $8.13 \pm 0.78^{\mathrm{b}}$ \\
Erythrocyte sedimentation & $16.75 \pm 2.85^{\mathrm{a}}$ & $8.88 \pm 0.54^{\mathrm{b}}$ \\
rate $(\mathrm{mm} / 24 \mathrm{~h})$ & $4.41 \pm 0.58$ & $3.87 \pm 0.35$ \\
Total leukocyte count $\left(10^{3} / \mu \mathrm{l}\right)$ & $10.71 \pm 6.08^{\mathrm{a}}$ & $4.42 \pm 0.28^{\mathrm{b}}$ \\
Neutrophil $\left(10^{3} / \mu \mathrm{l}\right)$ & $0.08 \pm 0.06$ & $0.17 \pm 0.04$ \\
Lymphocyte $\left(10^{3} / \mu \mathrm{l}\right)$ & $1.42 \pm 0.77^{\mathrm{a}}$ & $0.40 \pm 0.09^{\mathrm{b}}$ \\
Monocyte $\left(10^{3} / \mu \mathrm{l}\right)$ & $0.00 \pm 0.00^{\mathrm{a}}$ & $0.02 \pm 0.01^{\mathrm{b}}$ \\
Eosinophil $\left(10^{3} / \mu \mathrm{l}\right)$ & &
\end{tabular}

${ }^{a, b}$ Different superscripts in a row indicate significant differences between means $(\mathrm{p}<0.05)$ 
stimulation caused by active chronic Mycobacterium bovis infection (Stockham and Scott, 2008). This finding agreed with earlier reports in humans (Morris et al., 1989) and cattle (Javed et al., 2006) with tuberculosis.

Serum biochemical parameters are summarized in Table II. Means of serum ALT activity, albumin and urea levels of tuberculous cattle were significantly lower $(\mathrm{p}<0.05)$ than those of control, but serum globulin levels were significantly $(\mathrm{p}<0.05)$ higher in tuberculous cattle than in control. Means of serum AST and ALP activities, total protein, total cholesterol, creatinine and total bilirubin levels showed no significant $(p>0.05)$ differences between tuberculous and control cattle. The alterations in serum ALT activity, albumin and urea levels could have been caused by lesions in the liver and loss of its synthetic capacity (Stockham and Scott, 2008). Hypoalbuminemia has been reported in humans with tuberculosis (Morris et al., 1989). Increased serum globulin levels could have been caused by high levels of immunoglobulin production stimulated by chronic antigenic challenge by tubercle bacilli, similarly to what has been reported in humans with tuberculosis (Damburam et al., 2012).

\section{Table II}

Serum biochemical values (mean \pm standard error) of apparently healthy and tuberculous slaughtered cattle at Nsukka abattoir, Nigeria

\begin{tabular}{|c|c|c|}
\hline Serum biochemistry & $\begin{array}{c}\text { Tuberculous } \\
\text { cattle } \\
(\mathbf{n}=10)\end{array}$ & $\begin{array}{c}\text { Apparently } \\
\text { healthy cattle } \\
(n=40)\end{array}$ \\
\hline $\begin{array}{l}\text { Aspartate } \\
\text { aminotransferase (IU/L) }\end{array}$ & $83.00 \pm 5.67$ & $91.51 \pm 4.62$ \\
\hline $\begin{array}{l}\text { Alanine } \\
\text { aminotransferase (IU/L) }\end{array}$ & $33.48 \pm 2.85^{\mathrm{a}}$ & $39.07 \pm 2.14^{b}$ \\
\hline $\begin{array}{l}\text { Alkaline } \\
\text { phosphatase (IU/L) }\end{array}$ & $30.05 \pm 1.52$ & $33.25 \pm 1.99$ \\
\hline Total protein (g/dl) & $6.61 \pm 0.20$ & $6.60 \pm 0.15$ \\
\hline Albumin $(\mathrm{g} / \mathrm{dl})$ & $3.28 \pm 0.20^{a}$ & $3.46 \pm 0.14^{b}$ \\
\hline Globulin (g/dl) & $3.30 \pm 0.16^{a}$ & $3.15 \pm 0.17^{b}$ \\
\hline Total cholesterol (mg/dl) & $112.25 \pm 4.09$ & $114.11 \pm 3.68$ \\
\hline Total bilirubin (mg/dl) & $1.11 \pm 0.36$ & $1.55 \pm 0.17$ \\
\hline Creatinine (mg/dl) & $1.55 \pm 0.26$ & $1.45 \pm 0.15$ \\
\hline Urea (mg/dl) & $5.28 \pm 0.62^{a}$ & $9.98 \pm 0.97^{b}$ \\
\hline
\end{tabular}

a,b Different superscripts in a row indicate significant differences between means $(\mathrm{p}<0.05)$

\section{CONCLUSION}

Bovine tuberculosis was associated with normocytic normochromic anemia, increased ESR, total leukocyte, lymphocyte and eosinophil counts, and serum globulin levels, as well as decreased serum ALT activity, albumin and urea levels. Therefore, blood tests may be useful to establish the diagnosis of bovine tuberculosis in endemic areas.

\section{Acknowledgments}

The authors acknowledge the assistance of Nsukka abattoir staff, Enugu State, Nigeria, Dr. O.J. Okorie-Kanu for assistance in the immunochromatographic confirmation of bovine tuberculosis, and the Biomedical Research Support Unit of the Foundation for Education and Research on Health, Nsukka, for support in the hematological and serum biochemical analyses.

\section{REFERENCES}

Abubakar U.B., Aneh J.I., Abdulkadir I.A., Salisu I., Okaiyeto S.O., Kudi A.C., 2011. Bovine tuberculosis in Nigeria: A review. Vet. Res., 4: 24-27

Aliyu M.M., Adamu J.U., Bilyaminu Y.A., 2009. Current prevalence of tuberculosis lesions among slaughtered cattle in northeastern states of Nigeria. Rev. Elev. Med. Vet. Pays Trop., 62 (1): 13-16, doi: 10.19182/ remvt. 10088

Amin S., Khan M.A., Hashmi H.A., Rashid J., Khan M.S., 1990. Effects of tuberculosis on certain blood indices in buffaloes. Pak. Vet. J., 10: 92-93

Ayele W.Y., Neill S.D., Zinsstagg J., Weiss M.G., Pavlik I., 2004. Bovine tuberculosis: An old disease but a new threat to Africa. Int. J. Tuberculosis Lung Dis., 8: 924-937

Burtis C.A., Ashwood E.R., Bruns D.E., 2008. Tietz fundamentals of clinical chemistry, 6th Edn. Saunders, Elsevier, MO, USA

Corner L.A., 1994. Post mortem diagnosis of Mycobacterium bovis infection in cattle. Vet. Microbiol., 40: 53-63, doi: 10.1016/0378-1135(94)90046-9

Damburam A., Garbati M.A., Yusuph H., 2012. Serum proteins in health and in patients with pulmonary tuberculosis in Nigeria. J. Infect. Dis. Immun., 4: 16-19, doi: 10.5897/JIDI11.055

Ejeh E.F., Raji M.A., Bello M., Lawan F.A., Francis M.I., Kudi A.C., Cadmus S.I.B., 2014a. Prevalence and direct economic losses from bovine tuberculosis in Makurdi, Nigeria. Vet. Med. Int.: e904861, doi $10.1155 / 2014 / 904861$

Ejeh E.F., Adeshokan H.K., Raji M.A., Bello M., Musa J.A., Kudi A.C., Cadmus S.I.B., 2014b. Current status of bovine tuberculosis in Otukpo Nigeria. J Anim. Prod. Adv., 4: 501-507, doi: 10.5455/japa.20140821112921

Igbokwe I.O., Madaki I.Y., Danburam S., Ameh I.A., Aliyu M.M., Nwosu C.O., 2001. Prevalence of pulmonary tuberculous lesions in cattle slaughtered in abattoirs in northeastern Nigeria. Rev. Elev. Med. Vet. Pays Trop., 54 (3-4): 191-195, doi: 10.19182/remvt.9771

Javed M.T., Usman M., Irfan M., Cagiola M., 2006. A study on tuberculosis in buffaloes: Some epidemiological aspects along with haematological and serum protein changes. Vet. archiv, 76: 193-206

Kumar G.S., Lyer P.K.R., Prasad M.C., Sharma A.K., 1994. Tuberculosis in cattle: hematobiochemical studies. Indian J. Vet. Pathol., 38: 20-42

Lee S.W., Kang Y.A., Yoon Y.S., Um S., Lee S.M., Yoo C., Kim Y.W., et al., 2006. The prevalence and evolution of anaemia associated with tuberculosis. J. Korean Med. Sci., 21: 1028-1032, doi: 10.3346/jkms.2006.21.6.1028

Morris C.D., Bird A.R., Nell H., 1989. The haematological and biochemical changes in severe pulmonary tuberculosis. Quart. J. Med., 73: 1151-1159

Okoro O.J., Anosa G.N., Oboegbulem S.I., Nwanta J.A., Ezenduka E.V., 2014. Comparative assessment of post mortem inspection and immunochromatographic techniques for the detection of bovine tuberculosis in slaughter cattle in Nigeria. Trop. Anim. Health Prod., 46: 831-836, doi: 10.1007/s11250-014-0573-x

Olaniyi J.A., Aken'Ova Y.A., 2003. Haematological profile of patients with pulmonary tuberculosis in Ibadan, Nigeria. Afr. J. Med. Sci., 32: 239-242

Olivia V.M., Cezario G.A.G., Cocato R.A., Marcondes-Machado J., 2008 Pulmonary tuberculosis: haematology, serum biochemistry and the relation with the disease duration. J. Venom Anim. Toxins Trop. Dis., 14: 71-81, doi: 10.1590/S1678-91992008000100006

Rao V.N.A., Radmadas P., Dhinakran M., 1992. A study on the effect of tuberculosis on body weight and haemogram values of cattle. Cheiron, 21: $19-22$

Raufu I.A., Ameh J.A., 2010. Prevalence of bovine tuberculosis in Maiduguri, Nigeria - an abattoir study. Bull. Anim. Health Prod. Afr., 58: 119-123, doi 10.4314/bahpa.v58i2.62045

Stockham S.L., Scott M.A., 2008. Fundamentals of veterinary clinical pathology, 2nd Edn. Blackwell Publishing, IA, USA

Thrall M.A., Weiser M.G., 2002. Haematology. In: Laboratory procedures for veterinary technicians, 4th Edn. (Ed. Hendrix C.M.). Mosby, MO, USA, 29-74

Varello K., Pezzolato M., Mascarino D., Ingravalle F., Caramelli, M., Bozetta E., 2008. Comparison of histologic techniques for the diagnosis of bovine tuberculosis in the framework of eradication programs. J. Diagn. Invest., 20: 164-169, doi: 10.1177/104063870802000204

Weiss G., 2002. Pathogenesis and treatment of anaemia of chronic diseases. Blood Rev., 16: 87-96, doi: 10.1054/blre.2002.0193 


\section{Résumé}

Ihedioha J.I., Udeani I.J., Ezeasor C.K. Altérations biochimiques sériques et hématologiques chez les bovins Peuhls Blancs présentant des lésions tuberculeuses

Cette étude a évalué les altérations biochimiques hématologiques et sériques associées à la présence de lésions tuberculeuses chez des bovins zébus Peuhls Blancs à l'abattoir de Nsukka, dans l'Etat d'Enugu, au Nigeria. Le diagnostic a été confirmé par la technique immunochromatographique et l'histopathologie. Sur 567 bovins examinés, dix $(1,76 \%)$ avaient des lésions tuberculeuses. Les bovins tuberculeux ont présenté une anémie normochrome normocytaire, une leucocytose, une lymphocytose, une éosinophilie et une augmentation de la vitesse de sédimentation des érythrocytes. Les valeurs d'alanine aminotransférase sérique, d'albumine et d'urée on été par ailleurs significativement plus faibles $(p<0,05)$ et les valeurs de globuline sérique significativement plus élevées $(p$ $<0,05)$ que celles des témoins apparemment en bonne santé Nous avons conclu que la présence de tubercules chez les bovins était associée à une altération des paramètres biochimiques sériques et hématologiques, qui peuvent être pertinents pour établir le diagnostic ante mortem de la tuberculose.

Mots-clés : Bos indicus, bovin Peuhl Blanc, tuberculose, hématologie, biochimie, Nigeria

\section{Resumen}

Ihedioha J.I., Udeani I.J., Ezeasor C.K. Alteraciones serológicas bioquímicas y hematológicas en el ganado Fulani Blanco con lesiones tuberculosas

Este estudio asesoró las alteraciones serológicas bioquímicas y hematológicas asociadas con la incidencia de lesiones tuberculosas en el ganado Fulani Blanco, sacrificado en el matadero del estado de Enugu, en Nigeria. El diagnóstico se confirmó mediante la técnica de inmuno cromatografía e histopatología. De los 567 animales examinados, diez (1,76\%) presentaron lesiones tuberculosas. El ganado tuberculoso tenía anemia normocrómica normocítica, leucocitosis, linfocitosis, eosinofilia y una tasa de sedimentación eritrocítica elevada. También presentaron un nivel significativamente ( $p<0,05$ ) bajo de alanina aminotransferasa, albumina y urea, y globulina sérica significativamente $(p<0,05)$ elevada, con respecto a los animales controles aparentemente sanos. Se concluye que la ocurrencia de tubérculos en el ganado estuvo asociada con alteraciones en los parámetros bioquímicos séricos y hematológicos, los cuáles puede ser importantes para establecer un diagnóstico de tuberculosis ante mortem.

Palabras clave: Bos indicus, ganado bovino Fulani Blanco, tuberculosis, hematología, bioquímica, Nigeria 